\title{
Moisture conditions and energy consumption in heated crawl spaces in cold climates
}

\author{
Miimu Matilainen*, Jarek Kurnitski, Olli Seppänen \\ Laboratory of Heating, Ventilating and Air-Conditioning, Helsinki University of Technology, \\ P.O. Box 4100, Helsinki, FIN-02015 HUT, Finland
}

Received 28 February 2002; received in revised form 5 April 2002; accepted 7 April 2002

\begin{abstract}
A crawl space foundation is widely used in buildings and detached houses in northern countries. The relative humidity (RH) of the air in crawl spaces is the most critical factor of the mould growth in the structures of a crawl space. The objective of the study was to find out whether heating is a feasible alternative for crawl space moisture control with reasonably low energy consumption. The effects of summer heating in an outdoor air-ventilated crawl space with different ground covers and air change rates were simulated in this study. The simulations were carried out for an apartment building and a detached house. The effects of the control strategy, heating capacity, air change rate and ground covers on the energy consumption were studied. Mould growth index was used as performance criteria for acceptable conditions in the crawl space. To assess the sensitivity of the main simulation parameters a differential sensitivity analysis (DSA) was used. In the parametric simulations, the used ground covers were lightweight expanded clay aggregate (LWA), crushed stone (CS) and PVC. The control of heating was based on RH controller with the set point between 70 and $80 \%$ and a heater with heat output from 2.5 to $10 \mathrm{~W} / \mathrm{m}^{2}$ of crawl space area. It was shown that a thick layer of LWA prevents mould growth even without heating, but the layer with heating still provides lower RH An alternative method for moisture control is to use a ground cover without thermal insulation and heating of the crawl space. This method proved to be a good alternative to control mould growth. The specific energy consumption for heating of the crawl space was roughly the same order of magnitude in the studied apartment building and detached house. Annual specific energy consumption was generally low, within the range of 1.4$3.6 \mathrm{kWh} / \mathrm{m}^{2}$ of the crawl space area in most of studied cases. The energy consumption rose considerably when a lower set point value of RH was used, consequently the time when the heating is on was the highest when the set point value was lowest. With heating, it was possible to prevent any mould growth, i.e. to keep mould growth index equal to zero.
\end{abstract}

(C) 2002 Elsevier Science B.V. All rights reserved.

Keywords: Moisture; Lightweight expanded clay aggregate (LWA); Crawl spaces

\section{Introduction}

A crawl space foundation is widely used in buildings and detached houses in northern countries. Due to higher awareness of energy consumption the base floor $U$-value has decreased today to $0.2 \mathrm{~W} /\left(\mathrm{m}^{2} \mathrm{~K}\right)$, which corresponds approximately $20 \mathrm{~cm}$ mineral wool of insulation. The heat losses through base floor are smaller and, thus, a lower base floor $U$-value leads to a colder crawl space with higher relative humidity $(\mathrm{RH})$. Crawl spaces are typically ventilated with outdoor air but commonly there is a limited amount of ventilation ducts and opening in the foundation walls, and the air change rate is low. As there is often some organic material in the crawl space the conditions for mould

\footnotetext{
${ }^{*}$ Corresponding author. Tel.: +358-9-451-3604; fax: +358-9-451-3611. E-mail address: miimu@cc.hut.fi (M. Matilainen).
}

growth are favourable. In favourable conditions mould growth can start very quickly. Usually mould growth is noticed first as an unpleasant smell penetrating to the living spaces in the ground floor.

Moisture control in an outdoor air-ventilated crawl space is problematic due to time lag in thermal behaviour of the crawl space. Especially in the summer, the moisture conditions become problematic because the crawl space remains cold and outdoor air is usually warmer and has a higher moisture content than the air in the crawl space. Thus, in such conditions outdoor air can transport net moisture into the crawl space. This can be prevented by reducing the time lag between outdoor air temperature and the crawl space temperature. The time lag is caused by the high heat capacity of the ground soil and foundations. In principle, it can be decreased by increasing the air change rate or decreasing the heat capacity. 
In previous studies the following solutions for a crawl space moisture control are recommended:

- A thin ground cover, e.g. 10-5 cm lightweight expanded clay aggregate (LWA) and a higher air change rate (2$5 \mathrm{ach})$ in the summer. In the winter, an air change rate of 0.5 ach is sufficient [1].

- A highly insulated crawl space and a low air change rate of about $0.5 \mathrm{ach}$. For a highly insulated crawl space at least $30 \mathrm{~cm}$ LWA or $10 \mathrm{~cm}$ expanded polystyrene (EPS) ground cover is needed [2].

- Unventilated or warm crawl space without any outdoor air ventilation, which require obviously a very careful insulation work $[3,4]$.

According to earlier studies [1,2,5] a high risk for mould growth can usually be avoided with a sufficient thermal insulation on the ground. However, even in this case, moisture conditions may become problematic if the summer is exceptionally moist and rainy $[1,5]$. These uncertainties show a need for other solutions for moisture control, such as heating of the crawl space which is topic of this study.

The objective of this study is to find out how effectively moisture conditions in an outdoor air-ventilated crawl space can be controlled by means of heating. The principle of this solution is that the air change with outdoor air removes the moisture from crawl space and heating is used to control the $\mathrm{RH}$ in the crawl space. The heater is controlled by $\mathrm{RH}$ of the crawl space air. The controller switches the heater on when the set point (usually $75 \% \mathrm{RH}$ ) is exceeded. As an earlier study [1] recommends the use of a thermal insulation on the ground surface, all the studied crawl spaces have either moisture or thermal insulation in the ground. Since a wooden material has far higher risk for mould growth, the base floors of studied buildings are wooden. Firstly, the heat output was set constant and the effect of air change was studied. Secondly, the study focused on control strategy of heating and how it affects energy consumption and $\mathrm{RH}$ in the crawl space.

\section{Methods}

Simulations were carried out for an apartment building and a detached house with previously developed [1,9] and validated model which was improved with features for heating. The measured data are used to demonstrate the performance of the model. To assess the sensitivity of the main simulation parameters a differential sensitivity analysis (DSA) was used.

The simulation was carried out in an IDA simulation environment [6], where an RC network model of a crawl space was used. IDA is a modular simulation environment which consists of a neutral model format (NMF) translator, solver and modeller. The solver and the modules are separate, which makes it possible to change the mathematical formula of any component without changing the model description file. Via the translator, the modules can be used in several modular simulation environments. The used computer language for the models is NMF which serves as a readable document of the code as well [7,8].

The heat and moisture transfer equations are the same as reported in [1,9]. Heat transfer is modelled in structures and the ground (conduction, convection, and radiation only between ground and base floor). The model includes also the heat and moisture flows carried by ventilation. The conduction in the ground soil is modelled by means of semicircular heat flow patterns, "inner section", "outer section", and "wall 1" as shown in Fig. 1. The floor area of the crawl space is divided into two parts: the first meter
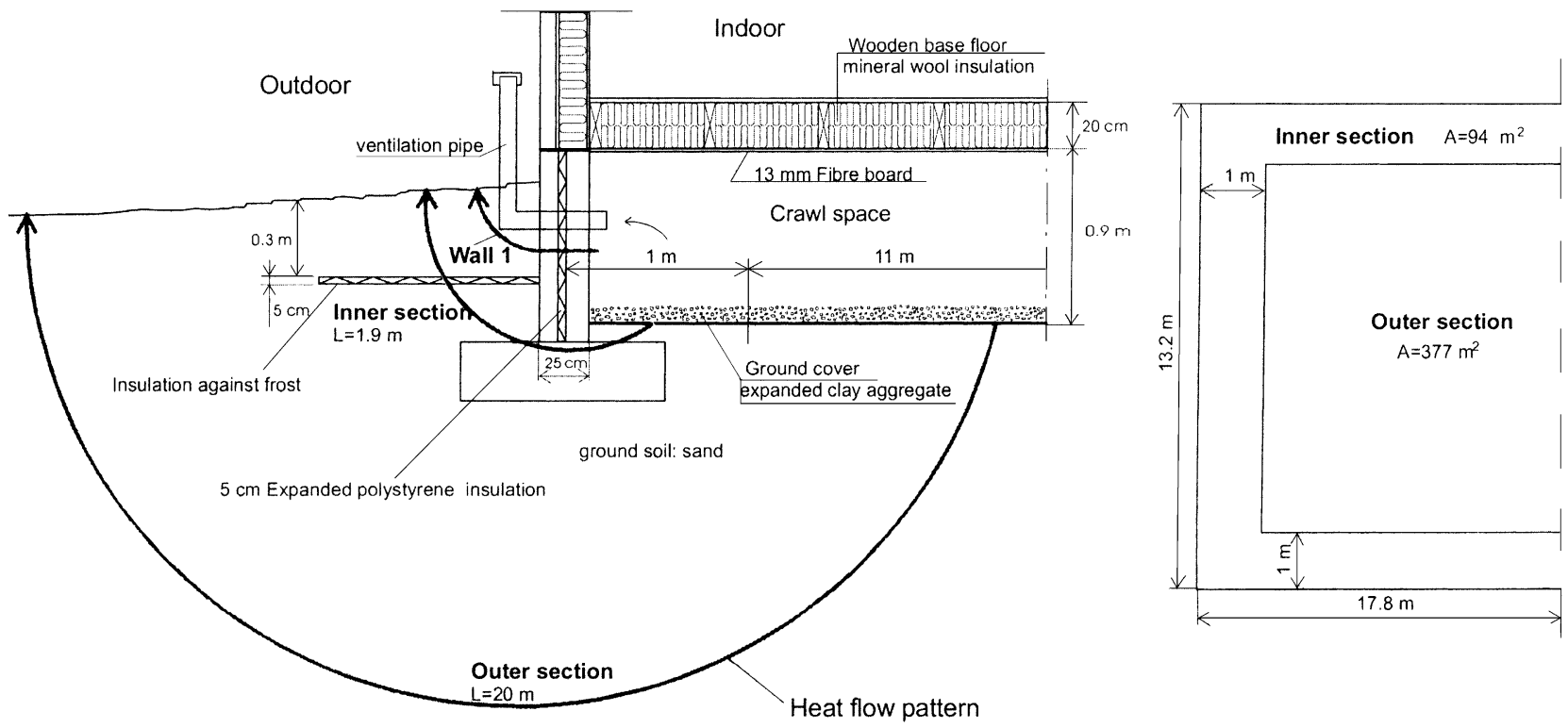

Fig. 1. A section of foundation with heat flow patterns and a plan of the modelled crawl space of an apartment building. 


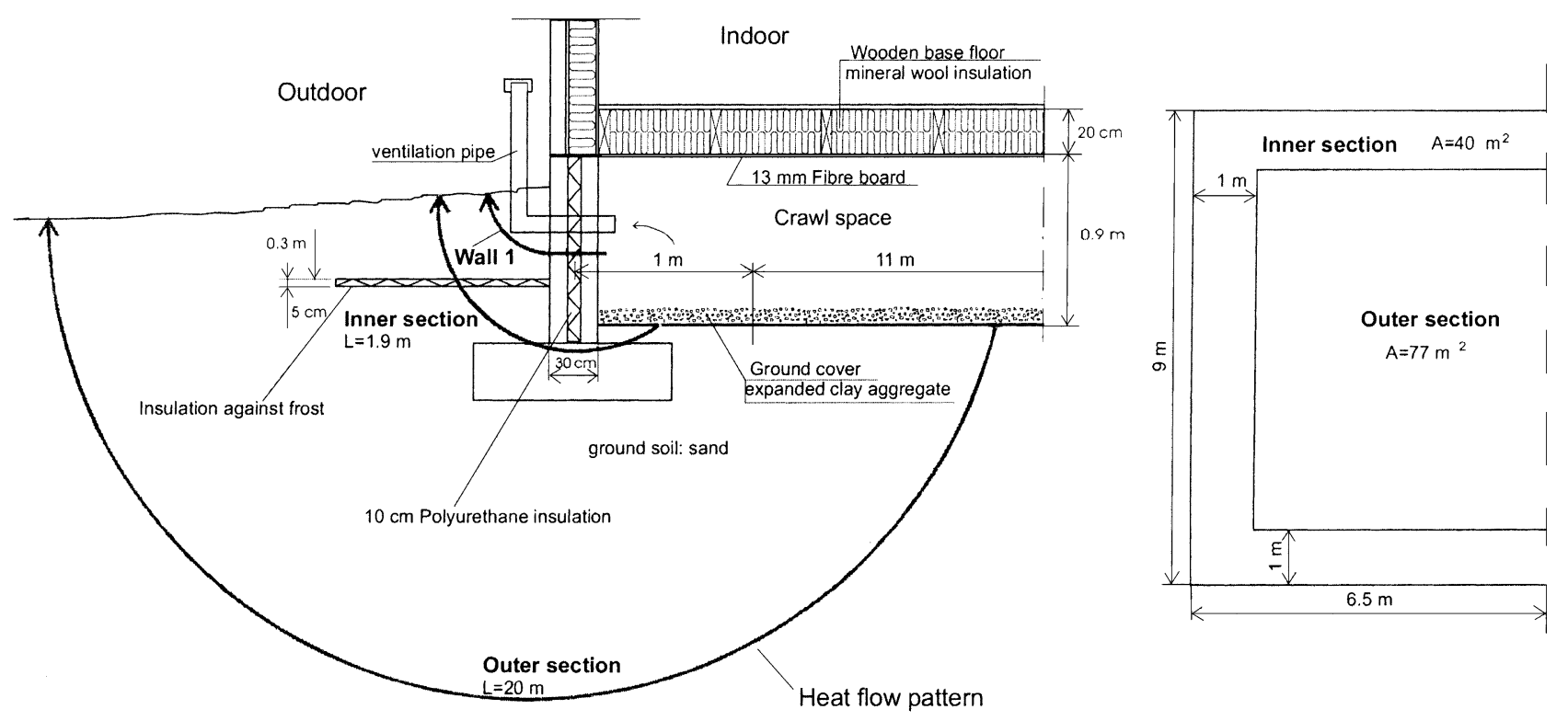

Fig. 2. A section with heat flow patterns and plan of the simulated crawl space of the detached house.

along the external walls (inner section) and the remainder (outer section) (Fig. 1). The ground surface in the modelled building was either covered by a PVC sheet, LWA or EPS.

\subsection{Studied buildings}

Simulations to study the effects of various ground covers and heating were carried out for the apartment building and detached house. The $U$-value of the wooden base floor (apartment building $470 \mathrm{~m}^{2}$ and detached house $117 \mathrm{~m}^{2}$ ) was $0.2 \mathrm{~W} /\left(\mathrm{m}^{2} \mathrm{~K}\right)$. The wooden base floor consists of $20 \mathrm{~cm}$ mineral wool insulation, the crawl space side of the base floor has a $13 \mathrm{~mm}$ fibre board. The simulations were carried out when the ground was covered with a 20 and $30 \mathrm{~cm}$ LWA insulation, a $20 \mathrm{~cm}$ crushed stone (CS), and a PVC sheet. In all simulated cases, the ground was insulated against frost (Fig. 1). Foundations in the apartment building were made from concrete with a $5 \mathrm{~cm}$ insulation and in the detached house from LWA bars with a $10 \mathrm{~cm}$ insulation (Fig. 2); an additional foundation (not shown in Fig. 1) was in the middle of the building $(0.9 \mathrm{~m} \times 0.2 \mathrm{~m})$. The air change rate in the simulations was $0.5-1$ ach.
The detached house $\left(117 \mathrm{~m}^{2}\right)$ was chosen for more detailed study due to its higher sensitivity for mould growth. The material properties of the ground covers used in the calculations are shown in Table 1.

Heating was controlled by an on/off-controller. The heat output was $2000 \mathrm{~W}\left(4.2 \mathrm{~W} / \mathrm{m}^{2}\right)$ in the apartment building and $1000 \mathrm{~W}\left(8.5 \mathrm{~W} / \mathrm{m}^{2}\right)$ in the detached house. The heater was usually turned on when RH in the crawl space exceeded $75 \%$. The dead band of the control system was 5\% (Fig. 3). To avoid unnecessary energy consumption heating was turned off for the heating season of buildings (from October to 30th April based on Finnish conditions and heating practice).

\subsection{Validation of the model}

The model calculates the temperature and moisture behaviour of the measured crawl space with sufficient accuracy (Fig. 4). A more detailed description of the model is given in [9-11], and the validation of the model is reported in [1]. As the weather data significantly affects the micro climate in the crawl space the weather data of a typical year 1998 was used [1].

Table 1

Material properties of ground covers used in the calculations

\begin{tabular}{llll}
\hline & EPS & LWA & CS \\
\hline Thermal conductivity $(\mathrm{W} /(\mathrm{m} \mathrm{K}))$ & 0.04 & 0.12 & 2.00 \\
Specific heat capacity $(\mathrm{J} /(\mathrm{kg} \mathrm{K}))$ & 900 & 950 & 800 \\
Volume weight $\left(\mathrm{kg} / \mathrm{m}^{3}\right)$ & 20 & 250 & 1520 \\
Moisture permeability $\left(\mathrm{m}^{2} / \mathrm{s}\right)$ & $1.0 \times 10^{-6}$ & $1.7 \times 10^{-5}$ & $1.7 \times 10^{-5}$ \\
Sorption isotherm given by $(0 ; 0)$, first and second points & & & $1.0 ; 94$ \\
$\quad$ First point $\left(w_{1}\left(\mathrm{~kg} / \mathrm{m}^{3}\right) ; \mathrm{RH}_{1}(\%)\right)$ & $0.2 ; 85$ & 2.0 & 2.0 \\
$\quad$ Second point $\left(w_{2}\left(\mathrm{~kg} / \mathrm{m}^{3}\right) ; \mathrm{RH}_{2}(100 \%)\right)$ & 0.6 & 94 \\
\hline
\end{tabular}




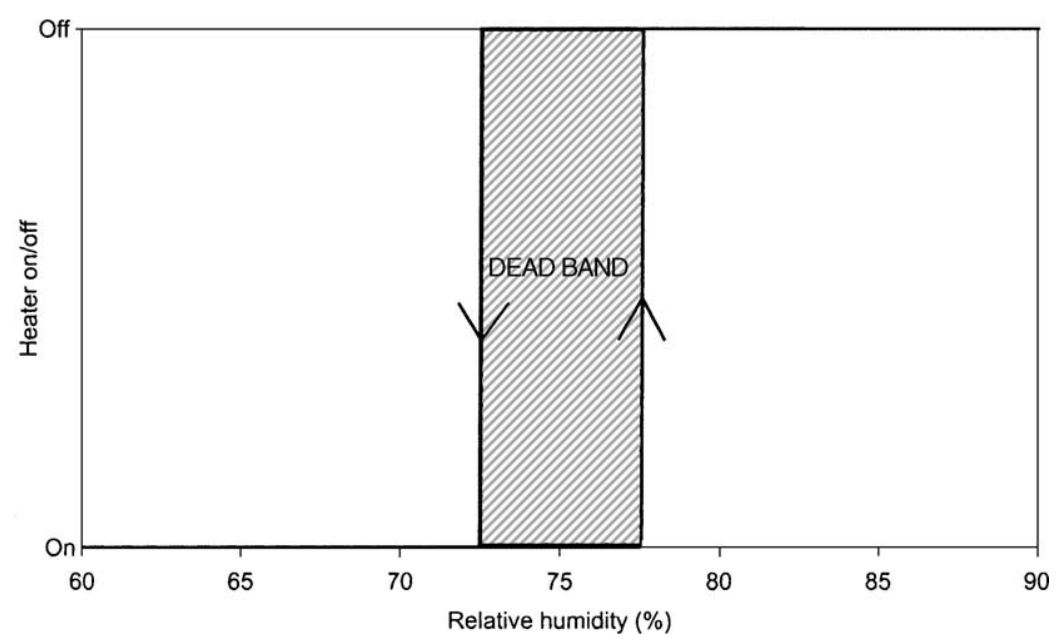

Fig. 3. The principle of the on/off control of the heating. Set point of RH was $75 \%$.

To assess the sensitivity of the main parameters used in the simulations a DSA was used. In DSA, the simulation is treated as a black box. In the base case of DSA, input parameters are chosen to give the best approximation of the measured data. Only one input parameter is changed at time for each simulation while the remaining inputs stay fixed at their base case values. One input parameter $i$ is changed to the value of $i+\Delta i$, where the $\Delta i$ is the change of input parameter $i$, and the simulation is repeated. As all the other input parameters are fixed the change in predicted parameter $\Delta p_{i}$ is, therefore, a direct measure of the effect of the change of the single input parameter. The simulations are repeated as many times as there are uncertain parameters. The effect
$\Delta p_{i}$ of each parameter change to the result is analysed. The underlying assumption in the DSA method is that the effect of an uncertainty is linear over the perturbance. To test the assumption a further simulation with parameter values $i-\Delta i$ is needed. If the magnitude on output parameter is the same but opposite direction, the assumption of the linearity is fulfilled. The total influence $\Delta p_{\text {tot }}$ of $I$ parameters can be calculated from Eq. (1). A more detailed description of the DSA method is given in $[12,13]$.

$$
\Delta p_{\mathrm{tot}}=\left(\sum_{i=1}^{I} \Delta p_{i}^{2}\right)^{1 / 2}
$$

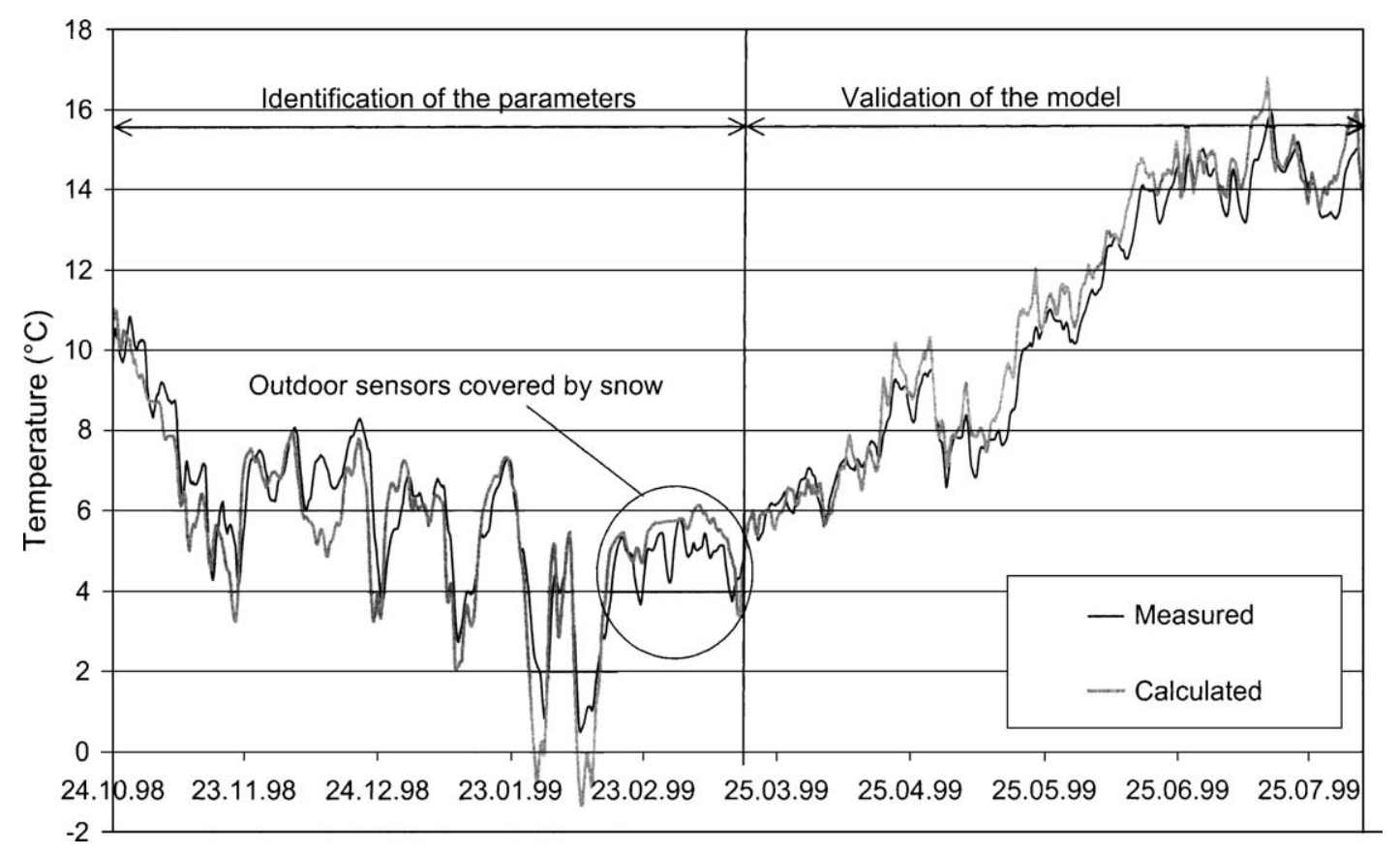

Fig. 4. Measured and calculated temperatures in the simulated crawl space [1]. 


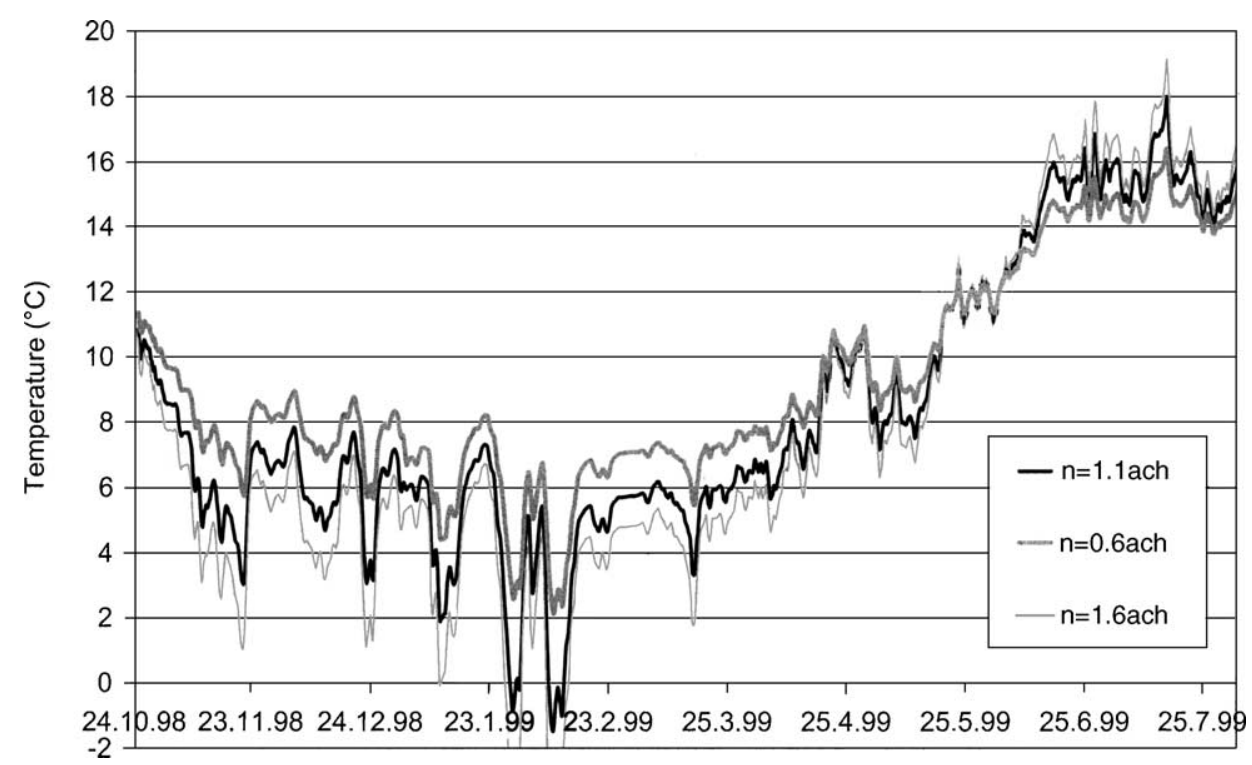

Fig. 5. Temperature of the crawl space simulated with the best estimate of air change rate (1.1 ach), and with upper and lower estimates. Daily average values.

where $\Delta p$ is the effect of $i$ th parameter change to the simulation output.

The sensitivity of four parameters was studied (density $x$ specific heat capacity, thermal conductivity, thickness of LWA layer, and air change rate). These input parameters were varied in the range of $\pm 30 \%$. First, the best estimate of the parameter was chosen by comparing the measured and calculated results. For example, for air change rate 1.1 ach gave the best estimate. When it was varied between 0.6 and 1.6 ach and the changes in the temperature fulfilled the linearity assumption, the best estimate was between the upper and lower estimates (Fig. 5).

The bar charts (Figs. 6 and 7) represent average monthly values of the temperature and RH in January and July. The linearity is fulfilled when the positive and negative changes in the input parameters affect the predicted value by a similar amount but in the opposite direction. The bar charts show that the sensitivity in temperature fulfils the linearity assumption, but in RH, only the thickness of LWA ground cover in January fulfils the linearity assumption. Thus, DSA shows that the thickness of LWA cover and air change rate have major influences on the temperature.

\subsection{Performance criteria}

The most important factors causing mould growth in a crawl space are $\mathrm{RH}$, temperature, nutrients and $\mathrm{pH}$. Nutrients and $\mathrm{pH}$ are not normally limiting factors as the majority of building materials contain nutrition suitable for moulds; even organic dust is sufficient for mould growth. Normally, the $\mathrm{pH}$ is a limiting factor for mould growth only in newly cast concrete. The temperature range of $5-35{ }^{\circ} \mathrm{C}$
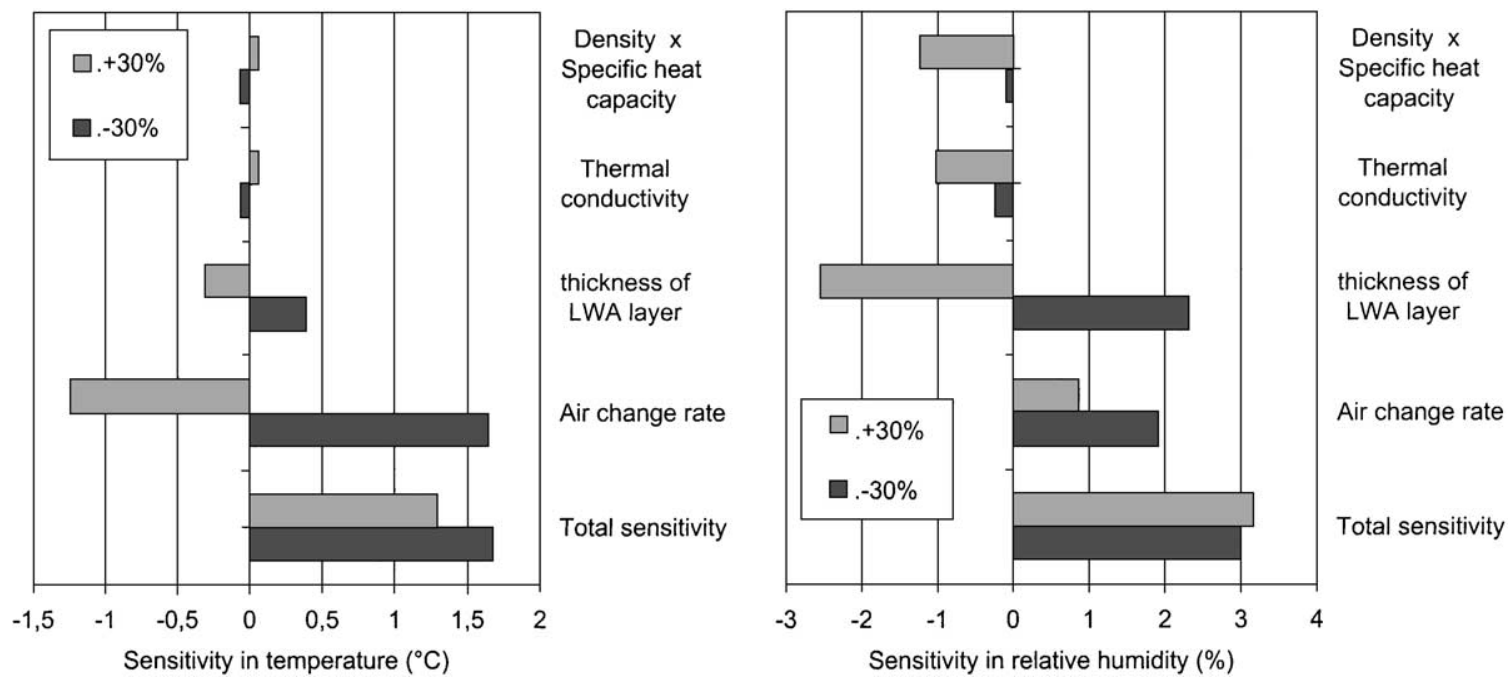

Fig. 6. Sensitivity in respect of studied parameter in temperature and RH in January. Average monthly values. 

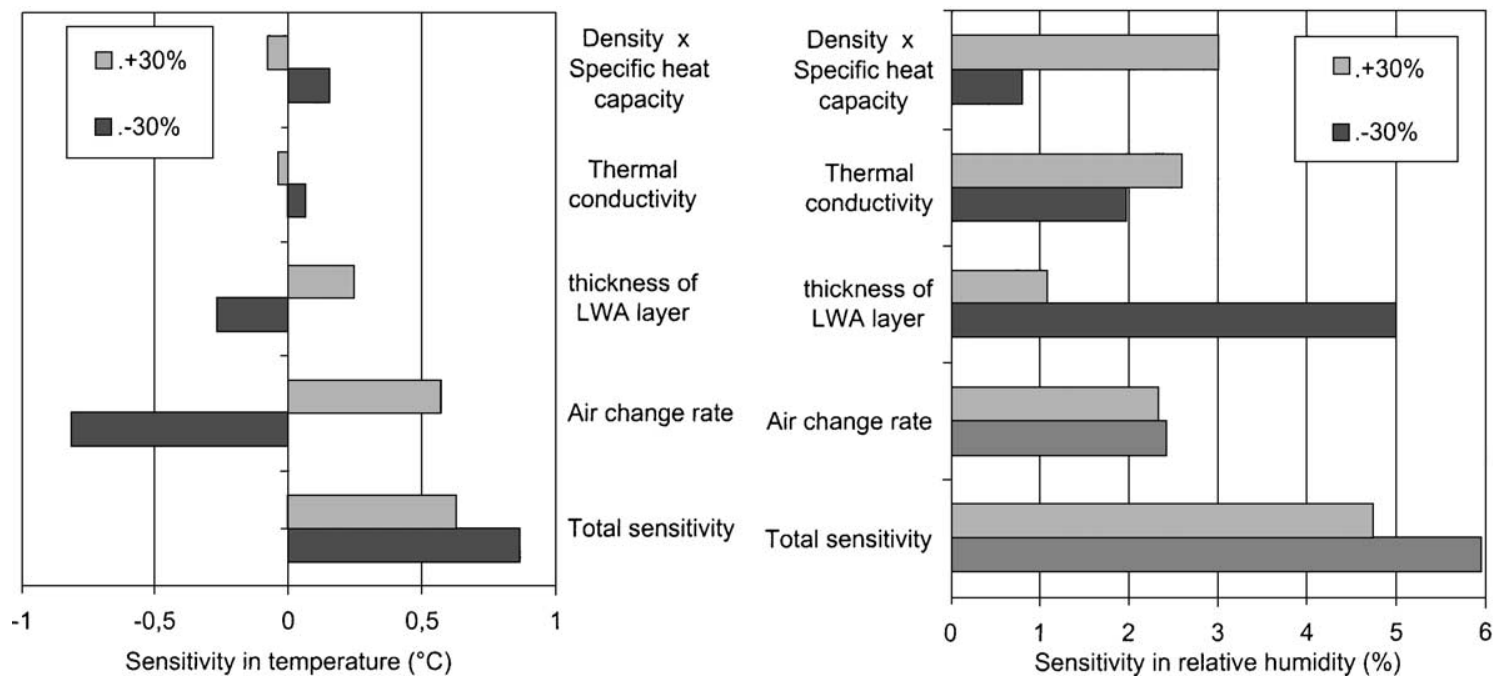

Fig. 7. Sensitivity in respect of studied parameter in temperature and RH in July. Average monthly values.

(optimum $20-25^{\circ} \mathrm{C}$ ) is suitable for many species of fungi, and the temperature in crawl spaces is nearly always in this range. This leaves $\mathrm{RH}$ as the critical factor for mould growth in the crawl spaces. The limit value for RH in crawl spaces is usually considered to be from 75 to $80 \%$ [4,14-17]. RH and temperature are strongly linked together. The thermal mass of the structures and ground soil affects the temperature behaviour of the crawl space. When the ground is not insulated, the crawl space remains cold during the summer due to the time lag caused by the thermal mass of the massive ground.

As a criterion, to compare the performance of heated and non-heated cases, an equation for mould growth, given in [18], was used. This equation estimates mould growth with mould growth index $M$, which can vary between 0 and 6 . The value of $M=0$ indicates no mould growth, $M=1$ some growth can be detected with microscope, $M=3$ some mould growth is detected visually, and $M=6$ very heavy and dense mould growth covers nearly $100 \%$ of the surface. It is not completely clear which value of $M$ is a relevant criterion. Since some mould growth can be detected at $M=1$, it is used as a criterion in this study. It was also tested if it is possible to achieve conditions with no mould growth $(M=0)$.

For varying temperature and humidity conditions Viitanen et al. [18] gives a differential equation for wood (pine and birch):

$$
\frac{\mathrm{d} M}{\mathrm{~d} t}=\frac{1}{7 \exp (-0.68 \ln T-13.9 \ln \mathrm{RH}+0.14 W-0.33 S Q+66.02)}
$$

where $M$ is the mould growth index, and $t$ is the time calculated in days. The mould growth index illustrates the growth rate. When conditions become unfavourable, the mould growth will slow down and the index $M$ will decrease. The delay of the mould growth caused by low RH (below the critical value of RH) is given in Eq. (2). The time (in days) is defined as a period from the beginning of the dry period $t-t_{1}$ :

$\frac{\mathrm{d} M}{\mathrm{~d} t}= \begin{cases}-0.032, & \text { when } t-t_{1} \leq 6 \mathrm{~h} \\ 0, & \text { when } 6 \mathrm{~h}<t-t_{1} \leq 24 \mathrm{~h} \\ -0.016, & \text { when } t-t_{1}>24 \mathrm{~h}\end{cases}$

In this study, the critical value for RH is considered to be $75 \%$, thus, Eq. (2) should be used when RH $<75 \%$. The set point of the humidity control of the air in the crawl space was also RH $75 \%$.

\section{Results}

\subsection{Crawl space conditions with heating}

The difference in RH in the summer between the heated and unheated cases are shown in Fig. 8. In the case of $20 \mathrm{~cm}$ CS the RH is on average over $10 \%$ higher when the heating is not used. Also, when $30 \mathrm{~cm}$ LWA ground cover is used, there is a clear difference in the RH levels. When a PVC ground cover without heating is used, $\mathrm{RH}$ rises over $90 \%$ in some periods showing ultimate need for moisture control.

Although with the $30 \mathrm{~cm}$ LWA cover the RH is higher when the heating is not used, it is still an acceptable solution, since the mould index $M$ is clearly below $M=1$ (Fig. 9). The PVC cover without heating causes mould growth but when the heating is used, the mould index is nearly zero in both cases.

In the apartment building, $20 \mathrm{~cm}$ CS without heating provides RH over $80 \%$, nearly $70 \%$ of the time in the summer from 1st May to 30th September (Fig. 10, left). With the $30 \mathrm{~cm}$ LWA, the RH exceeds $80 \%$, over $30 \%$ of the summer. When the heating is used, RH does not exceed $77.5 \%$, which is the upper value of the controller because of dead band (Fig. 10, left). In the detached house the crawl 


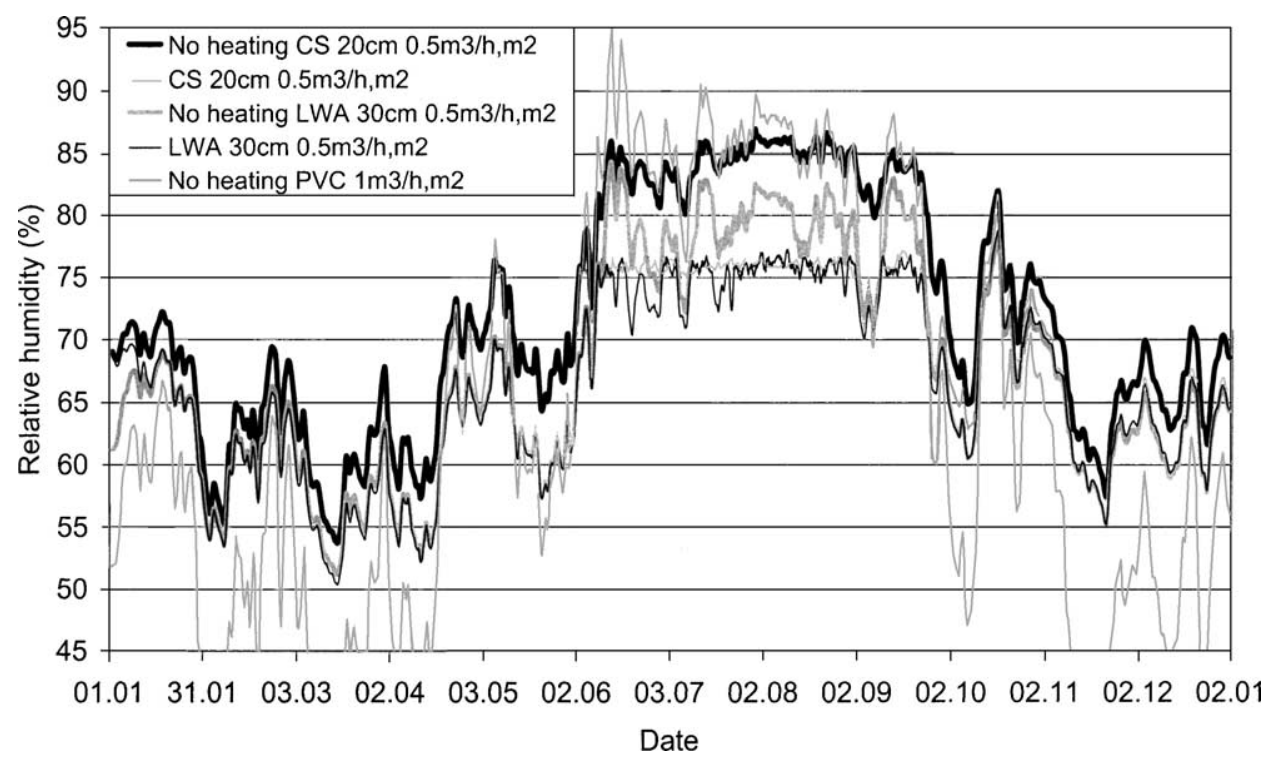

Fig. 8. RH in the crawl space of the detached house when the crawl space is unheated or heated. Operation time of heating was from 1st May to 30th September.

space RH is slightly lower, but basically the behaviour is similar as in the crawl space of the apartment building (Fig. 10, right). PVC ground cover without heating is unacceptable.

Doubling the air change rate from 0.5 to $1.0 \mathrm{~m}^{3} /\left(\mathrm{h} \mathrm{m}^{2}\right)$ does not cause any changes in RH in the summer in the apartment buildings crawl space if the heating is used (Fig. 11). The RH is under $77.5 \%$, except in a short period with the PVC ground cover. As the set point of the controller was $75 \%$ and the dead band $5 \%$, the heating performs as expected.

When the heating is used there is not any significant difference between air changes 0.5 and $1 \mathrm{~m}^{3} /\left(\mathrm{h} \mathrm{m}^{2}\right)$ in respect of mould growth (Table 2). Also the mould indices are very similar in both apartment and detached house. All ground covers are performing well when the heating is used. Thirty centimetre LWA cover has a higher mould growth index when the heating is not used, but it still remains clearly below the critical value $(M=1)$. Twenty centimetre CS and PVC ground covers definitely need heating to perform well.

\subsection{Energy consumption of the heating of the crawl space}

The results show that a high thermal mass of the ground cover has as significant effect on energy consumption of the crawl space heating. As on/off control is used, energy

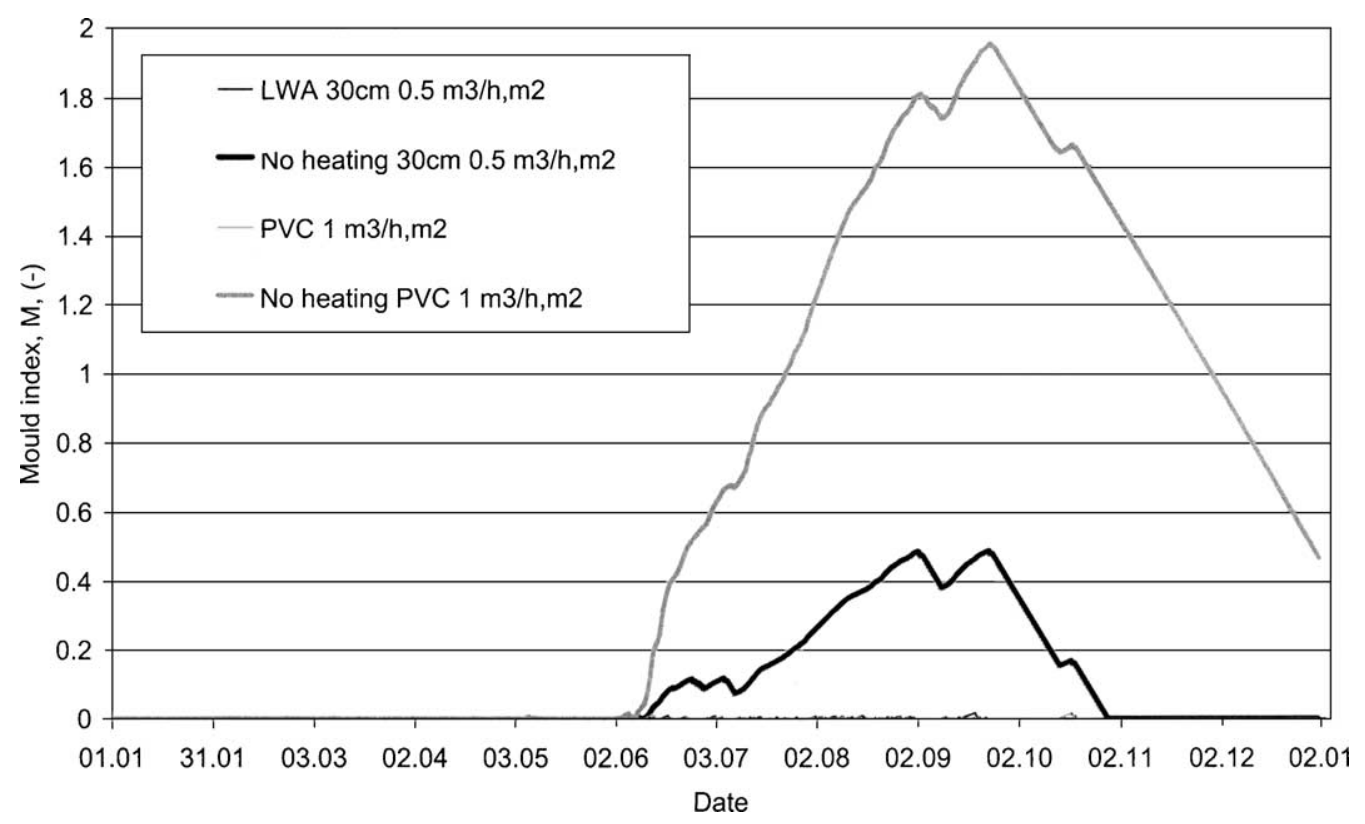

Fig. 9. Mould growth index $M$ with different ground covers and heating in the detached house. 

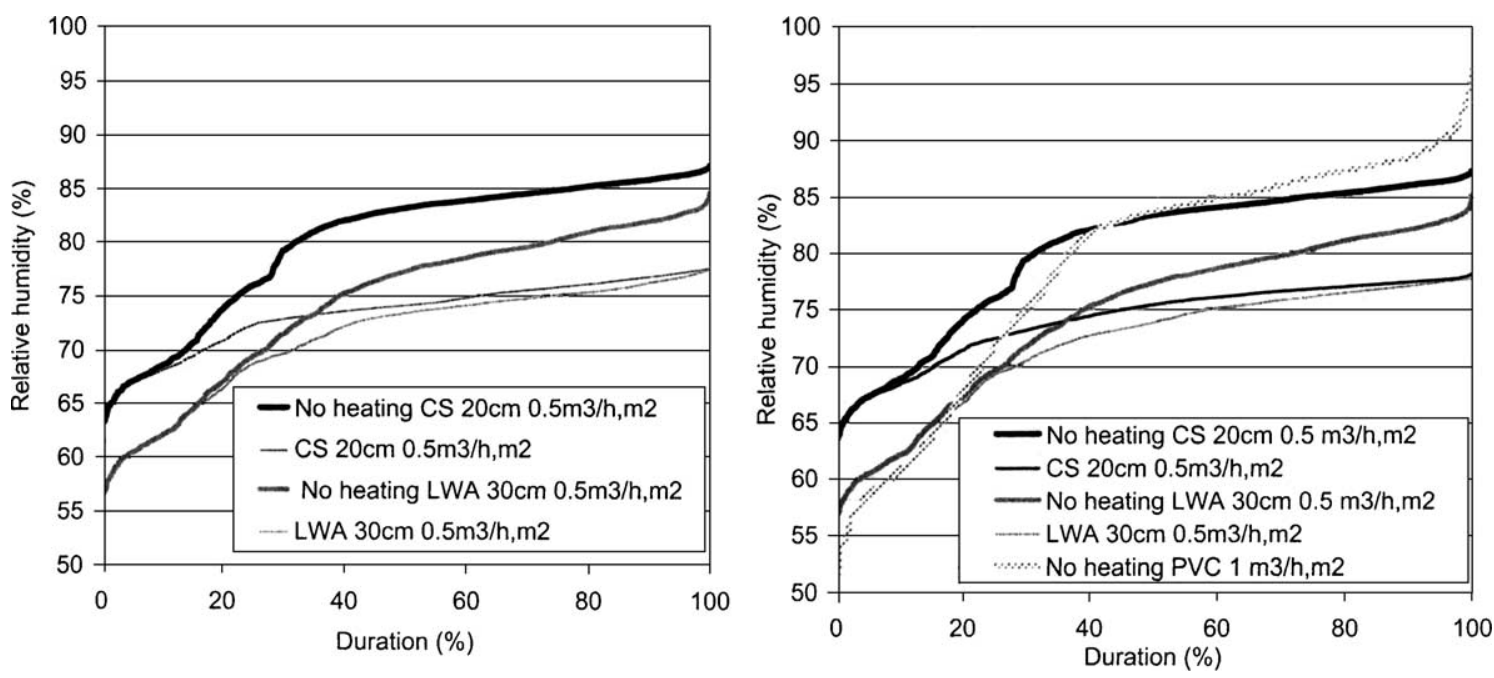

Fig. 10. RH with different ground covers and ventilation rates in the apartment building (left) and detached house (right). Duration curve is drawn for summer season from 1st May to 30th September when the heating in the crawl space is used.

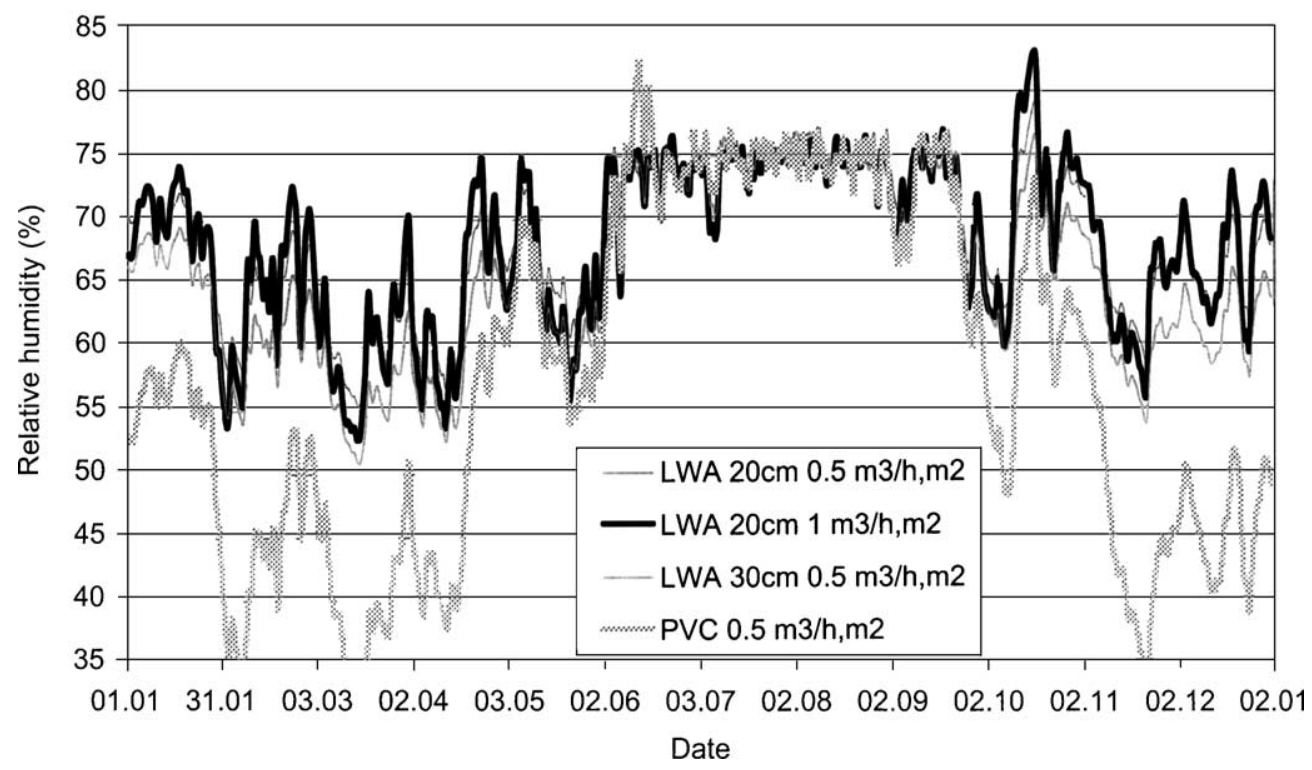

Fig. 11. RH with different ground covers and ventilation rates in the unheated and heated crawl space of the apartment building.

Table 2

Mould growth indices $M$ for the apartment building and detached house with different ground covers and air change rates

\begin{tabular}{llllll}
\hline Ground cover & \multicolumn{2}{l}{ Detached house } & & \multicolumn{2}{l}{ Apartment building } \\
\cline { 2 - 3 } & $\begin{array}{l}0.5 \mathrm{~m}^{3} / \\
\left(\mathrm{h} \mathrm{m}^{2}\right)\end{array}$ & $\begin{array}{l}1 \mathrm{~m} \mathrm{~m}^{3} / \\
\left(\mathrm{h} \mathrm{m}^{2}\right)\end{array}$ & & $\begin{array}{l}0.5 \mathrm{~m}^{3} / \\
\left(\mathrm{h} \mathrm{m}^{2}\right)\end{array}$ & $\begin{array}{c}1 \mathrm{~m} \mathrm{~m}^{3} / \\
\left(\mathrm{h} \mathrm{m}^{2}\right)\end{array}$ \\
\hline LWA $20 \mathrm{~cm}$ & 0.04 & 0.07 & & 0.02 & 0.05 \\
LWA $30 \mathrm{~cm}$ & 0.02 & 0.05 & & 0.01 & 0.04 \\
LWA $30 \mathrm{~cm}$, no heating & 0.49 & & 0.49 & \\
CS $20 \mathrm{~cm}$ & 0.03 & 0.05 & & 0.03 & 0.05 \\
CS $20 \mathrm{~cm}$, no heating & 1.55 & & 1.53 & \\
PVC & 0.01 & 0.01 & 0.03 & 0.05 \\
PVC, no heating & & 1.95 & & \\
\hline
\end{tabular}

consumption is directly dependent on the time when the heater is on. In the apartment building the crawl space with $20 \mathrm{~cm} \mathrm{CS}$ has the heating on very often (Fig. 12, top). The difference is remarkable compared to a $20 \mathrm{~cm}$ LWA cover (Fig. 12, bottom). The changes in the RH in the crawl space are slow, and the shortest time when the heating is on is approximately $6 \mathrm{~h}$.

For the detached house the performance of heating is basically the same as in the apartment building. However, $20 \mathrm{~cm}$ LWA cover needs less heating in the detached house than in the apartment building (Fig. 13, top).

In the apartment building the heating is used $23-32 \%$ of the time from 1st May to 30th September when the ground is covered with $20 \mathrm{~cm} \mathrm{CS}$ or PVC sheet (Table 3 ). When the air change rate is higher the time used for heating is longer as 

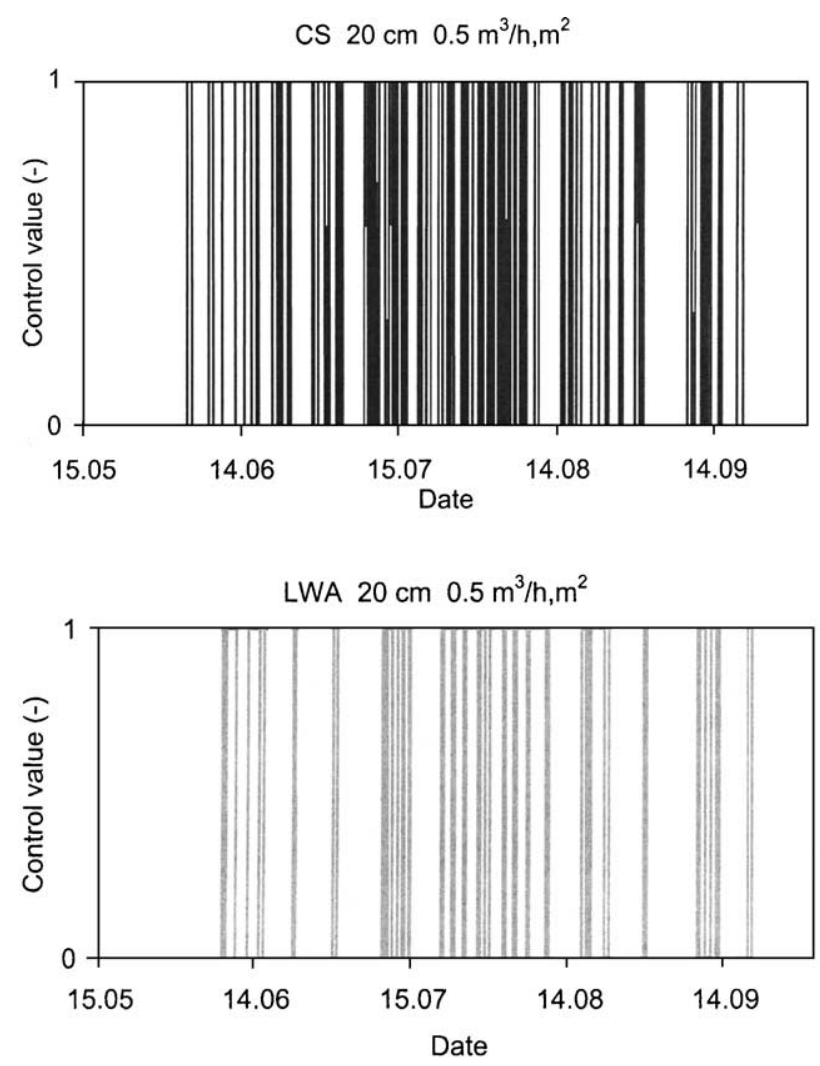

Fig. 12. Operation of heating in the apartment building with $20 \mathrm{~cm} \mathrm{CS}$ (top) and $20 \mathrm{~cm}$ LWA (bottom). Heating is turned on when the control value is 1 and turned off when the value is 0 .

well. Only the PVC cover exceeds the RH value of $77.5 \%$ in some percents of time, but all the other covers do not practically exceed the $\mathrm{RH}$ value of $77.5 \%$ (Table 3 ). The time when the heater is on, was shortest when $30 \mathrm{~cm}$ LWA with $0.5 \mathrm{~m}^{3} /\left(\mathrm{h} \mathrm{m}^{2}\right)$ was applied as a ground cover, and it did not exceed the RH value of $77.5 \%$.

In the detached house the heater is used less than in the apartment building (Table 4). In the cases of $20 \mathrm{~cm} \mathrm{CS}$ and $\mathrm{PVC}$ both with air change rates of $1 \mathrm{~m}^{3} /\left(\mathrm{h} \mathrm{m}^{2}\right)$, the time for

Table 3

The time when the heater is on and when the $77.5 \% \mathrm{RH}$ is exceeded in the apartment building

\begin{tabular}{llll}
\hline Ground cover & $\begin{array}{l}\text { Air change rate } \\
\left(\mathrm{m}^{3} /\left(\mathrm{h} \mathrm{m}^{2}\right)\right)\end{array}$ & $\begin{array}{l}\text { Time when } \\
\text { the heater } \\
\text { is on }(\%)\end{array}$ & $\begin{array}{l}\text { Time when the } \\
77.5 \% \mathrm{RH} \text { is } \\
\text { exceeded }(\%)\end{array}$ \\
\hline LWA $20 \mathrm{~cm}$ & 0.5 & 12.3 & 0 \\
LWA $20 \mathrm{~cm}$ & 1 & 17.5 & 0.03 \\
LWA $30 \mathrm{~cm}$ & 0.5 & 8.9 & 0 \\
LWA $30 \mathrm{~cm}$ & 1 & 14.3 & 0.05 \\
PVC & 0.5 & 24.5 & 3.3 \\
PVC & 1 & 31.8 & 7.4 \\
CS $20 \mathrm{~cm}$ & 0.5 & 23.0 & 0.1 \\
CS $20 \mathrm{~cm}$ & 1 & 29.7 & 0.03 \\
\hline
\end{tabular}
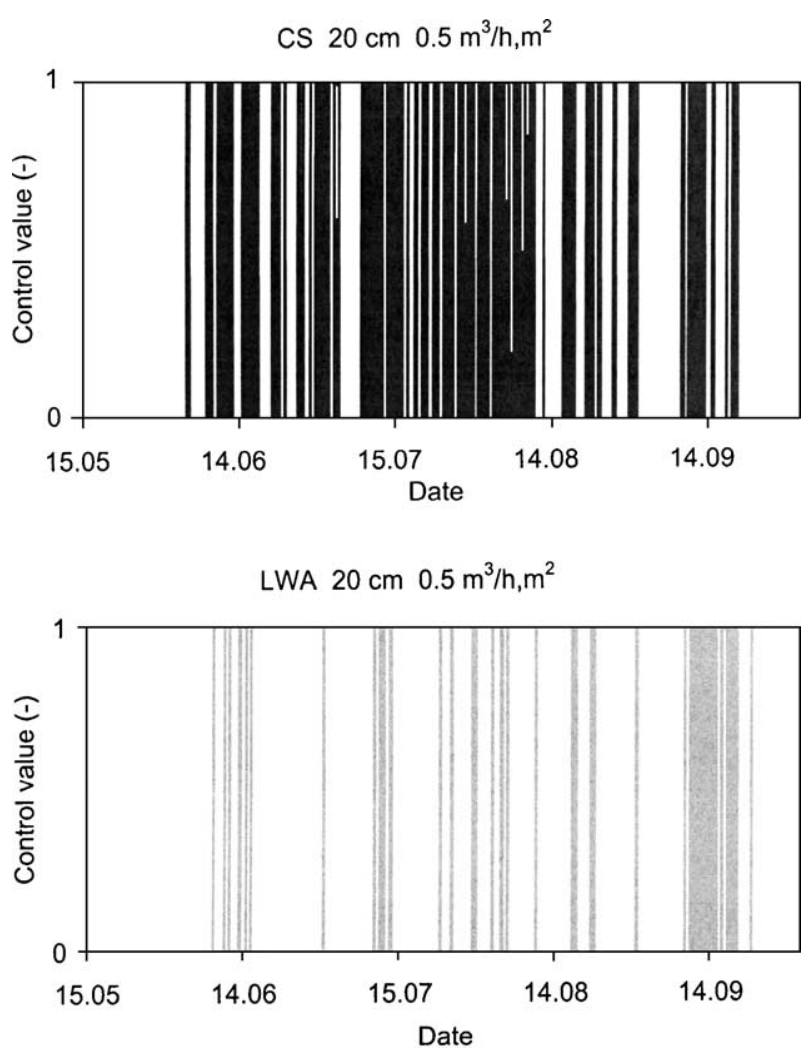

Fig. 13. Operation of heating in the detached house with $20 \mathrm{~cm}$ CS (top) and $20 \mathrm{~cm} \mathrm{LWA} \mathrm{(bottom).} \mathrm{Heating} \mathrm{is} \mathrm{turned} \mathrm{on} \mathrm{when} \mathrm{the} \mathrm{control} \mathrm{value} \mathrm{is} 1$ and turned off when the value is 0 .

heating is less than half of that for the apartment building. The time when the value of RH exceeds $77.5 \%$ is also short in every case in the detached house (Table 4).

The specific annual heat energy consumption does not differ much between the apartment building and detached house (Fig. 14). Suppose, the cases of $20 \mathrm{~cm}$ CS and PVC sheet show the highest heat consumption. The lowest heat consumption is less than one third of the highest one. The highest heat energy consumption was with PVC with $1 \mathrm{~m}^{3} /$

Table 4

The time when the heater is on and when the $77.5 \% \mathrm{RH}$ is exceeded in the detached house

\begin{tabular}{llll}
\hline Ground cover & $\begin{array}{l}\text { Air change rate } \\
\left(\mathrm{m}^{3} /\left(\mathrm{h} \mathrm{m}^{2}\right)\right)\end{array}$ & $\begin{array}{l}\text { Time when } \\
\text { the heater } \\
\text { is on }(\%)\end{array}$ & $\begin{array}{l}\text { Time when the } \\
77.5 \% \mathrm{RH} \text { is } \\
\text { exceeded }(\%)\end{array}$ \\
\hline LWA $20 \mathrm{~cm}$ & 0.5 & 6.7 & 0.2 \\
LWA $20 \mathrm{~cm}$ & 1 & 9.1 & 0.3 \\
LWA $30 \mathrm{~cm}$ & 0.5 & 5.3 & 0.4 \\
LWA $30 \mathrm{~cm}$ & 1 & 7.4 & 0.4 \\
PVC & 0.5 & 11.3 & 1.6 \\
PVC & 1 & 14.2 & 2.0 \\
CS $20 \mathrm{~cm}$ & 0.5 & 10.7 & 3.5 \\
CS $20 \mathrm{~cm}$ & 1 & 12.9 & 3.2 \\
\hline
\end{tabular}




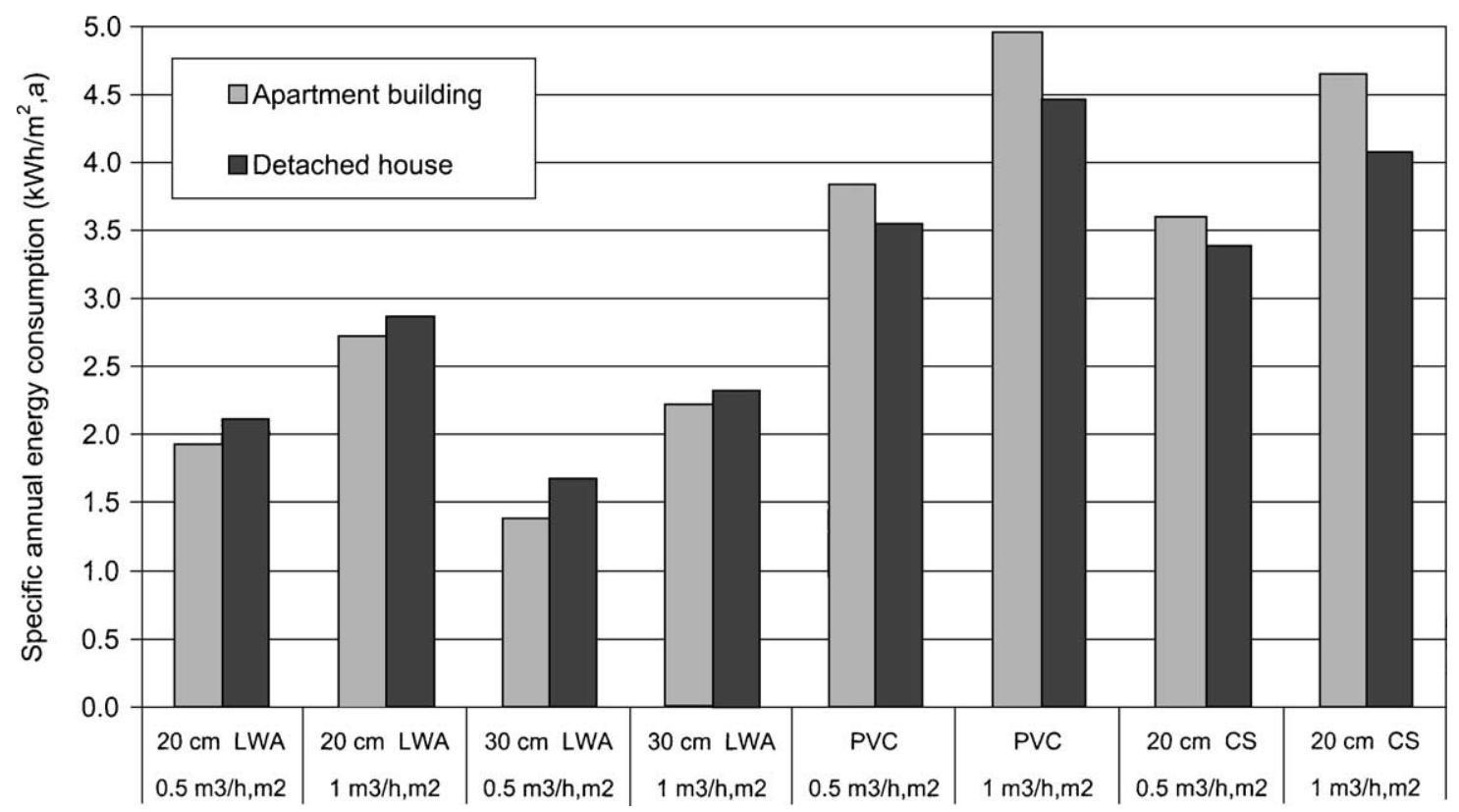

Fig. 14. Specific annual energy consumption for heating of a crawl space in the apartment building and detached house. Different ground covers and air change rates, the set point of RH was $75 \%$.

$\left(\mathrm{h} \mathrm{m}^{2}\right)$ and the lowest with $30 \mathrm{~cm}$ LWA with $0.5 \mathrm{~m}^{3} /\left(\mathrm{h} \mathrm{m}^{2}\right)$. The heat consumption is dependent on air change rate and lower air change rate gives lower energy consumption.

\subsection{Control strategy}

The wooden detached house was chosen for more detailed study as it is typical construction in northern countries and has a high sensitivity for mould growth. To determine the effect of the set point value and heat output rate on energy consumption and moisture conditions in the crawl space a further set of simulations were carried out: the set point was varied among 70, 75 and $80 \%$, and the heat output among $2.5,5$ and $10 \mathrm{~W} / \mathrm{m}^{2}$.

The energy consumption rose considerably when the set point of RH was lower (Fig. 15). At heat output of $5 \mathrm{~W} / \mathrm{m}^{2}$ the energy consumption in the case of RH set point $75 \%$ was from 45 to $66 \%$ of the energy consumption with the RH set point $70 \%$. Energy consumption was lowest with $30 \mathrm{~cm}$ LWA, and the case of $20 \mathrm{~cm}$ LWA showed only slightly higher values. The cases of PVC and $20 \mathrm{~cm} \mathrm{CS}$ consume roughly the same amount of energy.

Consequently, the time used for heating is the highest when the set point of RH is $70 \%$ (Fig. 16). The recommendation

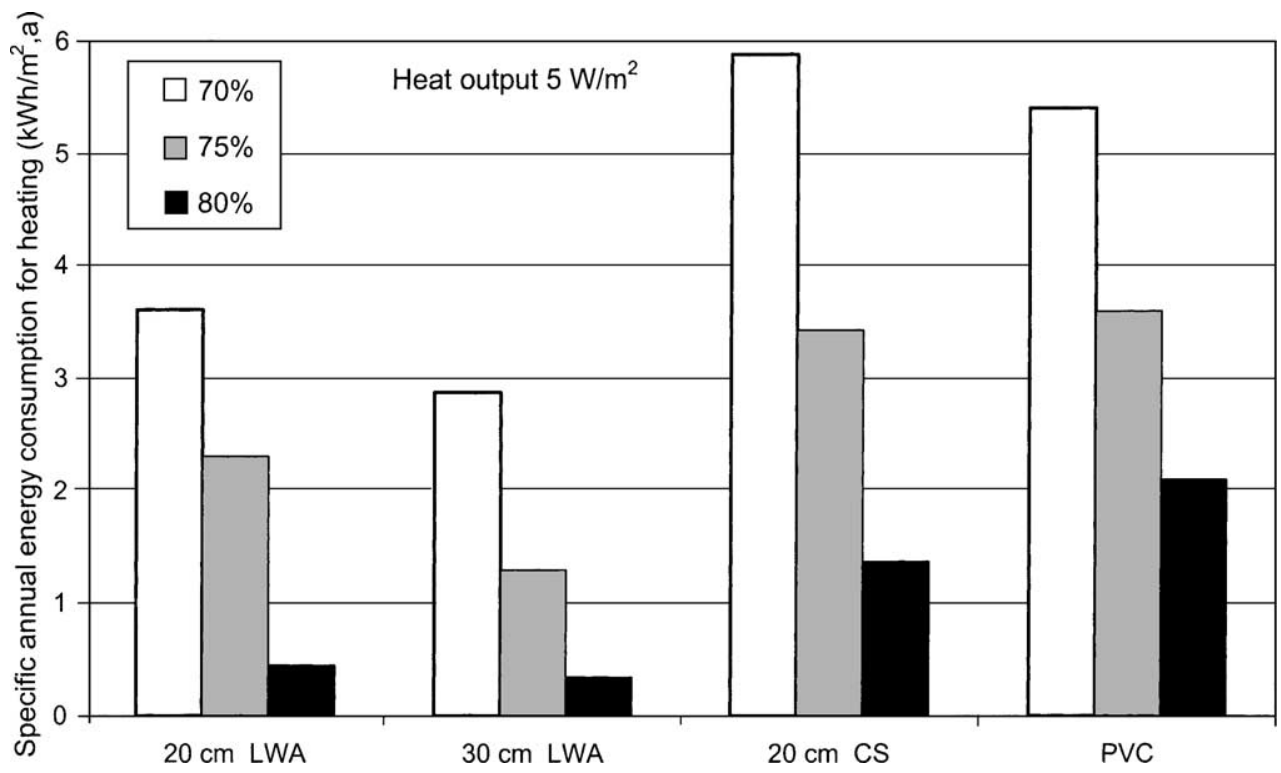

Fig. 15. Specific annual energy consumption with different set points of RH and ground covers. Detached house, air change rate $0.5 \mathrm{~m}^{3} /\left(\mathrm{h} \mathrm{m}^{2}\right)$. 


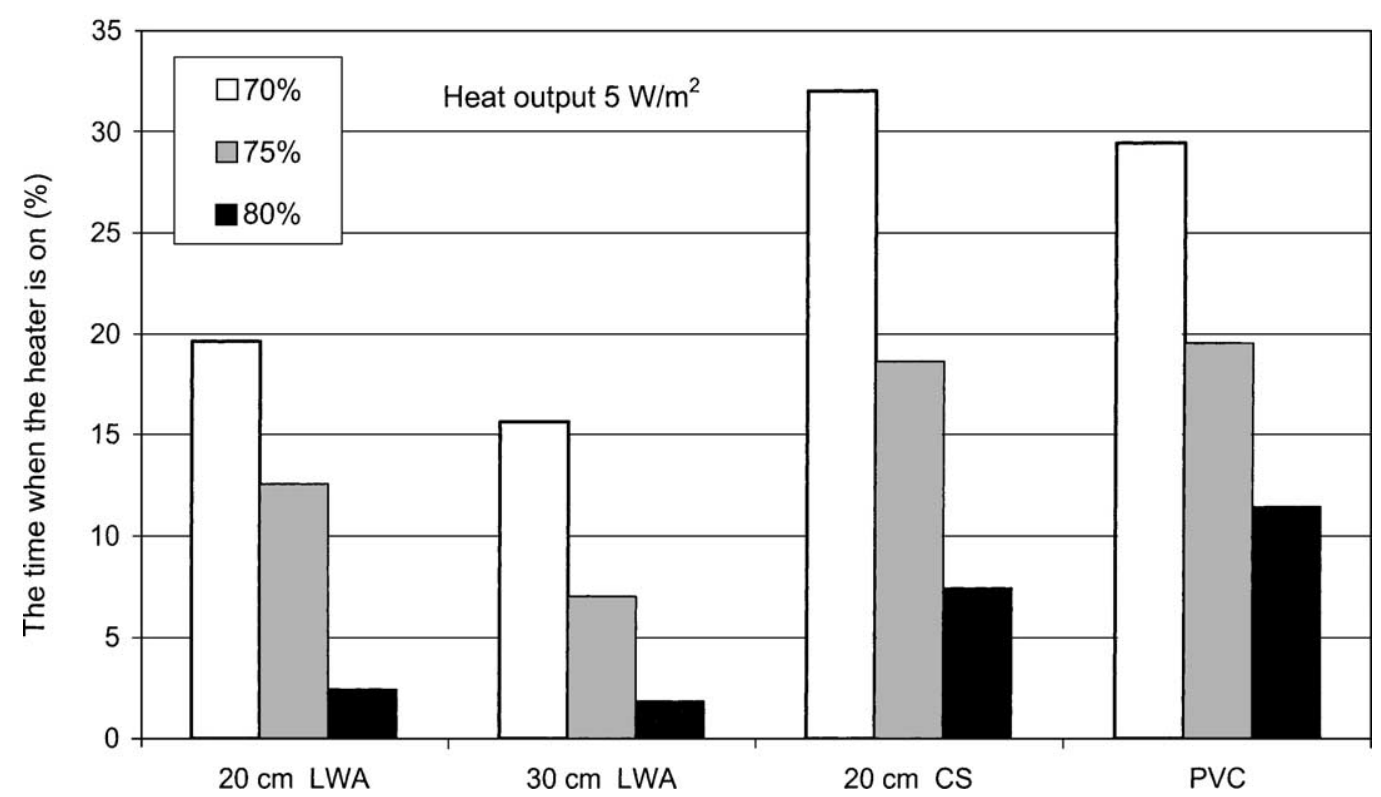

Fig. 16. Time (\%) when heater is on in the summer from the operation period (1st May to 30th September). Detached house, ventilation rate $0.5 \mathrm{~m}^{3} /\left(\mathrm{h} \mathrm{m}^{2}\right.$ ).

of an earlier study [2] to use a $30 \mathrm{~cm}$ LWA to prevent high $\mathrm{RH}$ seems to be true as with $75 \% \mathrm{RH}$ set point the heating is switched on only $7 \%$ of the time. With a $20 \mathrm{~cm}$ LWA cover the heating is on $13 \%$ of the time, and with CS and PVC sheet the heating is on roughly $20 \%$ of the time.

Even with the lowest set point of RH $(70 \%)$ and lowest heating power of $2.5 \mathrm{~W} / \mathrm{m}^{2}$, the RH in the crawl space with $30 \mathrm{~cm}$ LWA exceeds the upper limit of the set point of RH $(72.5 \%)$ only in $3 \%$ of the time (Fig. 17). Although the cases with $20 \mathrm{~cm} \mathrm{CS}$ and PVC ground cover consumed roughly the same amount of energy, PVC exceeds the RH set value in a significant time period at every RH set value, but $20 \mathrm{~cm} \mathrm{CS}$ only with the lowest RH set value showing the advantage of the moisture capacity of the ground cover.

Energy consumption, and other key parameters for simulated cases are shown in Table 5. In respect of preventing mould growth, all the cases are satisfactory. However, if the set point of RH is $80 \%$, the risk for mould growth increases (Table 5).

The results (Table 5) show that in some cases the higher heat output rate leads to slightly lower energy consumption. This can be explained by non-linear behaviour of the system and dead band of the controller. Energy consumption is highest (Table 6) when the average value of RH of the whole

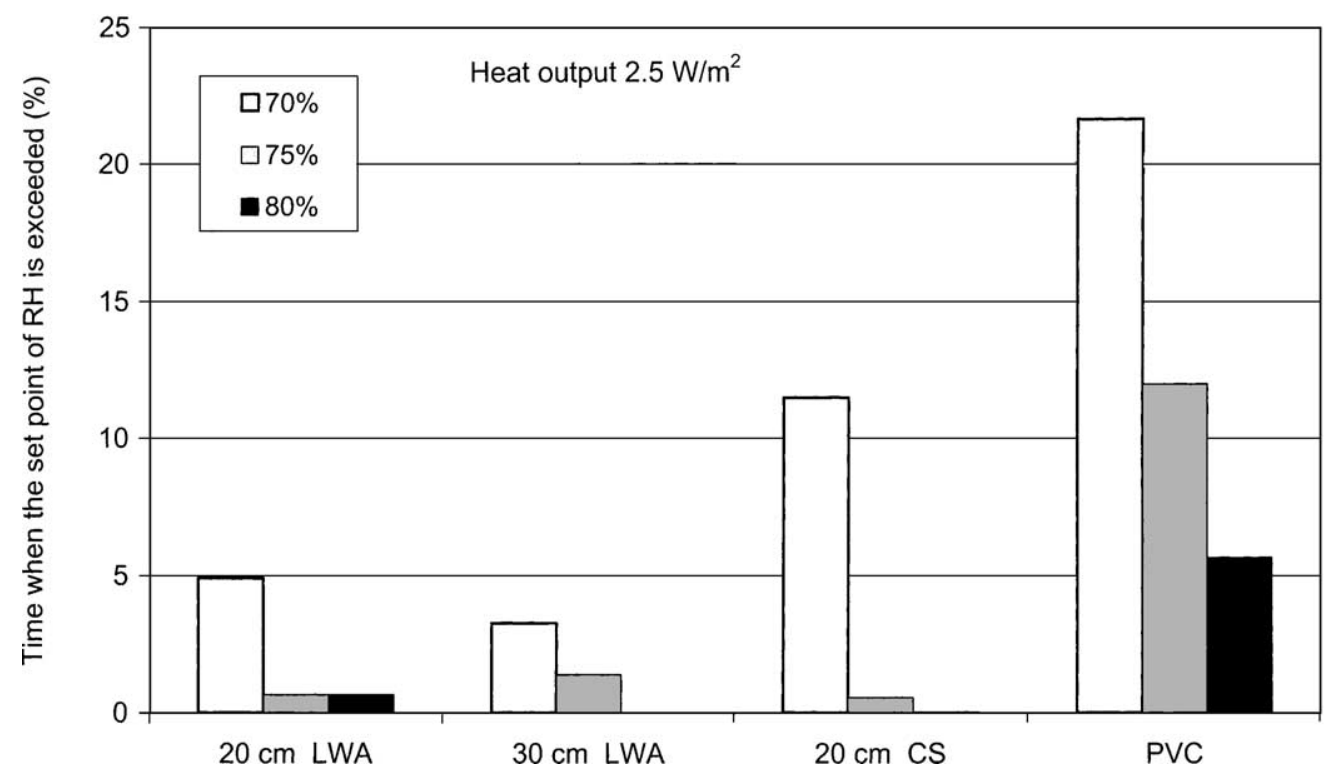

Fig. 17. Time (\%) when the set point of RH is exceeded in the summer from 1 st May to 30 th September. Detached house, ventilation rate $0.5 \mathrm{~m}^{3} /\left(\mathrm{h} \mathrm{m}^{2}\right)$. 
Table 5

Energy consumption, time used for heating and time when the control value is exceeded for different ground covers, air change rates and set points of RH

\begin{tabular}{|c|c|c|c|c|c|c|}
\hline Ground cover & $\begin{array}{l}\text { Heat output } \\
\left(\mathrm{W} / \mathrm{m}^{2}\right)\end{array}$ & $\begin{array}{l}\text { Set point } \\
\text { of } \mathrm{RH}(\%)\end{array}$ & $\begin{array}{l}\text { Heat consumption } \\
\left(\mathrm{kWh} / \mathrm{m}^{2}\right)\end{array}$ & $\begin{array}{l}\text { Time when the } \\
\text { heater is on }(\%)\end{array}$ & $\begin{array}{l}\text { Time when the control } \\
\text { value is exceeded }(\%)\end{array}$ & $\begin{array}{l}\text { Mould growth } \\
\text { index }\end{array}$ \\
\hline \multirow[t]{9}{*}{$\mathrm{CS} 20 \mathrm{~cm}$} & 2.5 & 70 & 5.7 & 62.0 & 11.4 & 0.01 \\
\hline & 2.5 & 75 & 3.6 & 39.7 & 0.5 & 0.03 \\
\hline & 2.5 & 80 & 1.6 & 17.4 & 0.0 & 0.75 \\
\hline & 5 & 70 & 5.9 & 32.0 & 0.2 & 0.01 \\
\hline & 5 & 75 & 3.4 & 18.6 & 0.7 & 0.03 \\
\hline & 5 & 80 & 1.4 & 7.5 & 0.7 & 0.85 \\
\hline & 10 & 70 & 5.4 & 14.6 & 4.3 & 0.01 \\
\hline & 10 & 75 & 3.4 & 9.3 & 3.0 & 0.03 \\
\hline & 10 & 75 & 1.3 & 3.5 & 2.0 & 0.88 \\
\hline \multirow[t]{9}{*}{ LWA $20 \mathrm{~cm}$} & 2.5 & 70 & 3.6 & 39.7 & 4.9 & 0.02 \\
\hline & 2.5 & 75 & 1.9 & 21.2 & 0.7 & 0.03 \\
\hline & 2.5 & 80 & 0.6 & 6.6 & 0.7 & 0.49 \\
\hline & 5 & 70 & 3.6 & 19.6 & 0.1 & 0.02 \\
\hline & 5 & 75 & 2.3 & 12.6 & 0.3 & 0.04 \\
\hline & 5 & 80 & 0.4 & 2.4 & 0.1 & 0.59 \\
\hline & 10 & 70 & 3.4 & 9.3 & 0.7 & 0.02 \\
\hline & 10 & 75 & 1.8 & 4.8 & 0.6 & 0.03 \\
\hline & 10 & 80 & 0.4 & 1.1 & 0.1 & 0.60 \\
\hline \multirow[t]{9}{*}{ LWA $30 \mathrm{~cm}$} & 2.5 & 70 & 2.8 & 30.8 & 3.3 & 0.01 \\
\hline & 2.5 & 75 & 1.4 & 15.3 & 1.4 & 0.02 \\
\hline & 2.5 & 80 & 0.4 & 4.2 & 0 & 0.30 \\
\hline & 5 & 70 & 2.9 & 15.6 & 0.1 & 0.01 \\
\hline & 5 & 75 & 1.3 & 7.1 & 0.2 & 0.02 \\
\hline & 5 & 80 & 0.3 & 1.9 & 0.1 & 0.34 \\
\hline & 10 & 70 & 2.6 & 6.9 & 0.4 & 0.01 \\
\hline & 10 & 75 & 1.1 & 3.1 & 0.2 & 0.03 \\
\hline & 10 & 80 & 0.3 & 0.8 & 0.1 & 0.35 \\
\hline \multirow[t]{9}{*}{ PVC } & 2.5 & 70 & 4.7 & 50.8 & 21.6 & 0.08 \\
\hline & 2.5 & 75 & 3.3 & 35.8 & 11.9 & 0.09 \\
\hline & 2.5 & 80 & 2.0 & 21.5 & 5.6 & 0.56 \\
\hline & 5 & 70 & 5.4 & 29.4 & 3.9 & 0.01 \\
\hline & 5 & 75 & 3.6 & 19.5 & 3.3 & 0.03 \\
\hline & 5 & 80 & 2.1 & 11.4 & 1.1 & 0.45 \\
\hline & 10 & 70 & 5.5 & 14.9 & 2.2 & 0.00 \\
\hline & 10 & 75 & 3.4 & 9.2 & 1.7 & 0.01 \\
\hline & 10 & 80 & 2.1 & 5.6 & 1.3 & 0.49 \\
\hline
\end{tabular}

period is lowest and average value of temperature is highest. For example, with PVC ground cover and RH set point of $75 \%$, energy consumption is the highest with heat output of $5 \mathrm{~W} / \mathrm{m}^{2}$, since in that case $\mathrm{RH}$ is $0.6 \%$ lower in relation to heat output $2.5 \mathrm{~W} / \mathrm{m}^{2}$.

\section{Discussion}

Earlier studies have recommend the use of ground covers with thermal insulations to prevent the mould growth in crawl spaces. They have also stressed a limited effect of air change rate on moisture control [1,2]. However, these measures may not be sufficient to keep RH below critical value during critical weather conditions. Weather conditions vary a lot during the year and due to the high thermal capacity of a crawl space the weather of the previous year will affect the conditions as well. It has been shown in [5] that micro climate has an important role in crawl space conditions. It seems that during summers with high humidity the rise of RH cannot be avoided in outdoor air-ventilated crawl spaces. Heating of a crawl space is not often considered to be a solution for moisture control due to its energy consumption. However, this study shows that with a reasonable ground insulation and air change rate the annual specific energy consumption of a heating is low, only about 2 $3 \mathrm{kWh} / \mathrm{m}^{2}$, which is for example usually about $1 \%$ of the energy consumption of a typical residential building [19].

In the studied crawl spaces, ventilation was used to remove moisture flow evaporated from ground and heating to control RH. The energy consumption which was very low, was slightly dependent on air change rate, but other factors, such as control strategy and thermal properties of ground covers had major influence on the consumed energy.

The accuracy of the simulation model is reasonably good as shown in [1]. The simulated data were compared to the 
Table 6

Detailed data of RH and temperature for some cases

\begin{tabular}{|c|c|c|c|c|}
\hline Ground cover and set point of $\mathrm{RH}$ & Heat output $\left(\mathrm{W} / \mathrm{m}^{2}\right)$ & Heat consumption $\left(\mathrm{kWh} / \mathrm{m}^{2}\right)$ & Average temperature $\left({ }^{\circ} \mathrm{C}\right)$ & Average $\mathrm{RH}$ \\
\hline $\mathrm{CS} 20 \mathrm{~cm}, \mathrm{RH}_{\mathrm{set}}=70 \%$ & $\begin{array}{l}2.5 \\
5 \\
10\end{array}$ & $\begin{array}{l}5.69 \\
5.87 \\
5.36\end{array}$ & $\begin{array}{l}15.05 \\
15.15 \\
15.01\end{array}$ & $\begin{array}{l}69.73 \\
69.28 \\
69.91\end{array}$ \\
\hline $\mathrm{CS} 20 \mathrm{~cm}, \mathrm{RH}_{\mathrm{set}}=80 \%$ & $\begin{array}{l}2.5 \\
5 \\
10\end{array}$ & $\begin{array}{l}1.60 \\
1.37 \\
1.28\end{array}$ & $\begin{array}{l}13.40 \\
13.31 \\
13.29\end{array}$ & $\begin{array}{l}77.15 \\
77.57 \\
77.68\end{array}$ \\
\hline LWA $20 \mathrm{~cm}, \mathrm{RH}_{\mathrm{set}}=80 \%$ & $\begin{array}{l}2.5 \\
5 \\
10\end{array}$ & $\begin{array}{l}0.61 \\
0.45 \\
0.39\end{array}$ & $\begin{array}{l}13.74 \\
13.65 \\
13.64\end{array}$ & $\begin{array}{l}75.17 \\
75.62 \\
75.69\end{array}$ \\
\hline LWA $30 \mathrm{~cm}, \mathrm{RH}_{\mathrm{set}}=70 \%$ & $\begin{array}{c}2.5 \\
5 \\
10\end{array}$ & $\begin{array}{l}2.83 \\
2.87 \\
2.55\end{array}$ & $\begin{array}{l}15.12 \\
15.13 \\
15.02\end{array}$ & $\begin{array}{l}68.15 \\
68.04 \\
68.52\end{array}$ \\
\hline $\mathrm{PVC}, \mathrm{RH}_{\mathrm{set}}=70 \%$ & $\begin{array}{l}2.5 \\
5 \\
10\end{array}$ & $\begin{array}{l}4.67 \\
5.39 \\
5.47\end{array}$ & $\begin{array}{l}14.11 \\
14.41 \\
14.38\end{array}$ & $\begin{array}{l}68.90 \\
67.44 \\
67.52\end{array}$ \\
\hline $\mathrm{PVC}, \mathrm{RH}_{\mathrm{set}}=75 \%$ & $\begin{array}{l}2.5 \\
5 \\
10\end{array}$ & $\begin{array}{l}3.28 \\
3.58 \\
3.37\end{array}$ & $\begin{array}{l}13.57 \\
13.67 \\
13.65\end{array}$ & $\begin{array}{l}71.40 \\
70.80 \\
70.92\end{array}$ \\
\hline
\end{tabular}

measured data and the difference between measured and calculated data was small. To assess the sensitivity of the main simulation parameters DSA method was used. However, the use of DSA is not straightforward as the underlying assumption of DSA is that the effect of an uncertainty is linear over the perturbance. Still, DSA is widely used since it enables the sensitivity of the programme outputs to input parameter changes to be explored directly [12]. It also permits the total uncertainty in a chosen output due to changes in many inputs. However, the total uncertainty is only strictly correct if the sensitivity to each individual input is independent of the value of the other inputs. This assumption is nevertheless not true for such thermal systems as buildings or crawl spaces. In this study, DSA method was useful in analysing the sensitivity of studied parameters on temperature. The sensitivity results regarding $\mathrm{RH}$ did not have any physical meaning as its behaviour in respect of varied parameters was not linear. The most important factors having strongest effect on crawl space thermal behaviour were air change rate and thermal properties of ground cover.

The energy consumption of heating did not decrease linearly when the heat output was decreased. The model was validated against the measured data in [1] and it did calculate correctly the changes in RH and temperature. The reason for this unlinearity seems to be the control strategy used, especially the dead band of controller. In many cases, the highest heat output gave slightly lower energy consumption. This seems to be due to a high heat output which can heat up the crawl space fast and then heating is switched off within the range of dead band. In some cases the medium heat output rate gave the highest energy consumption. In these cases, the average $\mathrm{RH}$ during the whole heating period was $0.5 \%$ lower and temperature about $0.1{ }^{\circ} \mathrm{C}$ higher in relation to other heat outputs, which explains the higher energy consumption. However, these differences in energy consumption at varied heat output rates were so small that they do not have any significance in practice.

\section{Conclusion}

The RH in an heated outdoor air-ventilated crawl space was significantly lower compared to unheated ones. The RH was over $10 \%$ higher in unheated case and it exceeded $90 \%$ if the ground cover had no thermal insulation. The advantage of heating was significantly higher if the ground cover had high thermal conductivity. LWA ground cover performed well even without heating. Plastic sheet and CS ground covers absolutely required moisture control and their energy consumption for heating was highest.

To assess the sensitivity of the main simulation parameters on results, a DSA was used. The sensitivity in temperature fulfilled the linearity assumption of the DSA method, but in $\mathrm{RH}$ it did not. DSA showed that the thickness of LWA cover and air change rate have major influence on the temperature. It was not possible to apply the DSA method for RH.

Specific annual energy consumption for heating a crawl space was generally low, within the range of $1.4-3.6 \mathrm{kWh} /$ $\mathrm{m}^{2}$, in most cases at a set point of $75 \% \mathrm{RH}$, and it was roughly the same for the apartment building and detached house.

Energy consumption was strongly dependant on set point of RH. The energy consumption increased considerably when the set point of RH was lowered: $5 \%$ lower set point corresponds $30-60 \%$ longer heating time. A drop of $5 \%$ in the set point of $\mathrm{RH}$ to $70 \%$ doubled the energy consumption 
in some cases. The change of heat output from 2.5 to $10 \mathrm{~W} /$ $\mathrm{m}^{2}$ did not cause any significant effect on energy consumption. Doubling the air change rate increased the energy consumption by $20-60 \%$. This shows that excessively high air change rates should be avoided for example in naturally ventilated crawl spaces, but the range between 0.5 and 1 ach may be considered optimal.

Heating kept the RH very effectively below the set point - the set point was exceeded only during a few hours in 1 year. This applies within all studied heat output range from 2.5 to $10 \mathrm{~W} / \mathrm{m}^{2}$. The only exception with insufficient heat output was PVC and CS with the RH set value of $70 \%$. In these cases, the set value was exceeded by $15 \%$ of operation time with PVC and 9\% with CS.

However, heating prevented all mould growth already at the lowest heat output rate of $2.5 \mathrm{~W} / \mathrm{m}^{2}$. Mould growth index was less than 0.1 in all cases already with the set point of $75 \%$ RH.

The results may be formulated as a design guideline for cold climate craw space design: heated crawl space needs heat output rate $>2.5 \mathrm{~W} / \mathrm{m}^{2}$, a controller with set point of $75 \% \mathrm{RH}$, and air change rate of $0.5 \mathrm{~m}^{3} /\left(\mathrm{h} \mathrm{m}^{2}\right)$.

\section{Acknowledgements}

The Finnish National Technology Agency is gratefully acknowledged for sponsoring this project.

\section{References}

[1] M. Matilainen, J. Kurnitski, Crawl space moisture control by means of the moisture capacity and thermal insulation of the ground cover, and ventilation, Building and Environment (2000).

[2] M. Matilainen, J. Kumitski, Moisture conditions in highly insulated outdoor ventilated crawl spaces in cold climates, Energy and Building (2001).

[3] O. Åberg, The unventilated crawl space foundation, Building Physics in Nordic Countries, 1990.
[4] L.E. Nevander, B. Elmarson, Fukt Handbokpraktik och teori (Handbook of Moisture, Practice and Theory), AB Svensk Byggtjänst, Stockholm, 1994 (in Swedish).

[5] C. Svensson, Effekter av åtgarder i uteluftsventilerade krypgrunder med fukt- och mögeiskador (Effects of Remedial Measures in Outdoor Air-Ventilated Crawl Spaces with Mould and Moisture Problems; Licentiate Thesis), Rapport TVBH-3038 Lund 2001, Department of Building Physics, LTH, Lund, 2001 (in Swedish).

[6] P. Sahlin, Modelling and Simulation Methods for Modular Continuous Systems in Buildings, Doctoral Dissertation, Stockholm, 1996.

[7] P. Sahlin, E.F. Sowell, The Neutral Model Format for Building Simulation, Stockholm, 1996.

[8] P. Sahlin, An introduction to the neutral model format, NMF Handbook, NMF Version 3.02, Stockholm, 1996

[9] J. Kurnitski, M. Matilainen, Moisture conditions in outdoor airventilated crawl spaces of apartment buildings in a cold climate, Energy and Buildings 33 (2000) 15-29.

[10] J. Kurnitski, M. Vuolle, Simultaneous calculation of heat, moisture, and air transport in a modular simulation environment, Proceedings of the Estonian Academic Science 6 (1) (2000) 25-47.

[11] J. Kurnitski, Ground moisture evaporation in crawl spaces, Building and Environment 36 (3) (2000) 359-373.

[12] K.J. Lomas, H. Eppel, Sensitivity analysis techniques for building thermal simulation programs, Energy and Buildings 19 (1992) 21-44.

[13] I. MacDonald, P. Strachan, Practical application of uncertainty analysis, Energy and Buildings 33 (2001) 219-227.

[14] I. Samuelsson, Moisture control in crawl space, ASHRAE Technical Data Bulletin 10 (3) (1994) 58-64.

[15] L.E. Nevander, B. Elmarson, Fuktdimensionering av träkonstruktioner, Riskanalys, Swedish Council Building Research, Report R38, 1991.

[16] A.-L. Pasanen, T. Juutinen, M.J. Jantunen, P. Kalliokoski, Occurrence and moisture requirements of microbial growth in building materials, International Journal of Biodeterioration and Biodegradation 30 (1992) 273-283.

[17] H. Viitanen, A.-C. Ritschkoff, Mould Growth in Pine and Spruce Sapwood in Relation to Air Humidity and Temperature, Report no. 221, Department of Forest Products, Swedish University of Agricultural Sciences, Uppsala, 1991.

[18] H. Viitanen, A. Hanhijarvi, A. Hukka, K. Koskela, Modelling mould growth and decay damages, in: Proceedings of the Healthy Buildings 2000, Vol. 3, Espoo, Finland, pp. 341-346.

[19] I. Aho, M. Haakana, M. Marttila, H. Kinnunen, M. lindholm, A. Pirinen, Rakennusten energiatodistus, Loppuraportti (Energy Certification for Buildings, Report), Ympänstöministeriö, Suomen ympäristö 232, Helsinki, 1998. 